\title{
Urodimento
}

REVISTA DE ESTUDOS EM ARTES CÊNICAS

E-ISSN 2358.6958

\section{A cidade canção e João Pereira: Passos do poeta grão de areia no Teatro Caipira do norte do Paraná}

Douglas Kodi

Lincoln Guilherme Copceski

Para citar este artigo:

KODI, Douglas; COPCESKI, Lincoln Guilherme. A cidade canção e João Pereira: Passos do poeta grão de areia no Teatro Caipira do norte do Paraná. Urdimento - Revista de Estudos em Artes Cênicas, Florianópolis, v. 2, n. 41, set. 2021.

do) DOI: http:/dx.doi.org/10.5965/1414573102412021e0103

Este artigo passou pelo Plagiarism Detection Software| iThenticate 


\title{
A cidade canção e João Pereira:
}

\section{Passos do poeta grão de areia no Teatro Caipira do norte do Paraná}

Douglas Kodi ${ }^{1}$

Lincoln Guilherme Copceski²

\begin{abstract}
Resumo
O Teatro Caipira ocorreu durante as décadas de 60 e 70 no estado do Paraná e de São Paulo e encontra-se distante de ser contemplado, com a devida importância, na História do teatro brasileiro. Este artigo pretende contribuir para o preenchimento da lacuna de uma historiografia do Teatro Caipira e para o entendimento de sua trajetória. Para isso, é analisada a vida e carreira do ator, poeta e compositor João Pereira, autodenominado, poeta grão de areia, e também é analisada a peça Corisco antes de ser cangaceiro (1968), do mesmo artista, com o objetivo de apreender os meios de produção cênica, dramaturgia e temáticas presentes no Teatro Caipira. Por fim, e para além de tudo, deseja manter viva a memória de João Pereira.
\end{abstract}

Palavras-chave: Teatro Caipira. Teatro popular. História de atores. Maringá. Teatro paranaense.

\section{The cidade canção and João Pereira: Steps of the poet grain of sand at Teatro Caipira in northern Paraná}

\begin{abstract}
The Teatro Caipira occurred during the 1960s and 1970s in the states of Paraná and São Paulo, and is far from being contemplated, with due importance, in the history of Brazilian theatre. The present article strives to fill the gap of a historiography of the Teatro Caipira and to understand its trajectory. For this, the life and career of the actor, poet and composer João Pereira, self-denominated poet grain of sand, is analyzed, as well as the piece Corisco antes de ser cangaceiro (1968), by the same artist, with the objective of apprehending the means of scenic production, dramaturgy and themes present in the Teatro Caipira. Finally, and beyond all, to keep alive the memory of João Pereira.
\end{abstract}

Keywords: Teatro Caipira. Popular theatre. History of actors. Maringá. Paraná theatre.

${ }^{1}$ Doutorando em Teatro pela Universidade do Estado de Santa Catarina (UDESC) e Mestre pela mesma Universidade. Graduado na Universidade Estadual de Maringá (UEM). douglaskodiO7@gmail.com

(9) http://lattes.cnpq.br/2547501265624081 (iD https://orcid.org/0000-0003-3322-9920

${ }^{2}$ Mestrando em Tecnologia e Sociedade, pela Universidade Tecnológica Federal do Paraná (UTFPR). Graduado em Comunicação e Multimeios pela Universidade Estadual de Maringá (UEM). lcopceski@gmail.com

(6) http://lattes.cnpq.br/2508009153148752

(iD https://orcid.org/0000-0002-3610-8836 


\section{La cidade canção y João Pereira: \\ Huellas del poeta grano de arena en el Teatro Caipira en el norte de Paraná}

Resumen

El Teatro Caipira se produjo durante las décadas de 1960 y 1970 en los estados de Paraná y São Paulo, y está lejos de ser contemplado, con la debida importancia, en la historia del teatro brasileño. El presente artículo pretende llenar el vacío de una historiografía del Teatro Caipira y comprender su trayectoria. Para ello, se analiza la vida y trayectoria del actor, poeta y compositor João Pereira, autodenominado poeta grano de arena, así como la obra Corisco antes de ser cangaceiro (1968), del mismo artista, con el objetivo de aprehender los medios de producción escénica, la dramaturgia y los temas presentes en el Teatro Caipira. Por último, y más allá de todo, para mantener viva la memoria de João Pereira.

Palabras-clave: Teatro Caipira. Teatro popular. Historia de los actores. Maringá. Teatro paranaense. 
Bem, a nossa vida é uma estrada comprida, cheia de curvas bem como se vê. Tanto sacrifício pra tanta subida, depois na derriba precisa descer. Se sobe e se desce por muitas estradas sem ver pela frente o que tem que passar. De vez em quando uma encruzilhada atravessa a estrada pra gente penar. A estrada da vida que eu tenho é penosa e eu nela caminho por fim encontrar. Eu levo a vida de forma enganosa e caminho cantando só para não chorar (João Pereira). ${ }^{3}$

Assim João Pereira, o poeta grão de areia, recita os versos sertanejos de Raul Torres \& Florêncio que escutava na rádio durante sua infância, ao mesmo tempo em que rememora a história de sua carreira e do chamado Teatro Caipira na cidade de Maringá-PR, conhecida como cidade canção ${ }^{4}$.

Este artigo aborda o fenômeno do Teatro Caipira — assim denominado pelos próprios atuantes - por meio da vida e obra do poeta, compositor e ator João Pereira (1932-). Para isso foram utilizadas entrevistas ${ }^{5}$ realizadas com o próprio artista e obras de historiadores e jornalistas (Dias, R. B. e Gonçalves, 2011; Leal, 2016) que abordaram a História da arte em Maringá. Para dar concretude aos temas e aos métodos de composição cênica no referido fenômeno, também foi abordado o texto teatral Corisco antes de ser cangaceiro (1968), do próprio João Pereira.

Tanto o movimento do Teatro Caipira como a obra de João Pereira são pouco abordados no meio acadêmico e na historiografia da região Norte do Paraná. Uma das poucas menções encontradas sobre o estilo teatral no Brasil vem do pesquisador Odirlei Dias Pereira, em sua dissertação No rádio e nas telas: O rural da música sertaneja de sucesso e sua versão cinematográfica (2008). Trata-se de uma análise das músicas da dupla Tonico \& Tinoco e de como foram transpostas para o teatro (caipira) e posteriormente para o cinema, tendo como principal

\footnotetext{
${ }^{3}$ Esta fala, assim como todas as outras vinculadas a João Pereira usadas neste artigo, foi retirada de uma entrevista realizada em setembro de 2019, concedida por João Pereira aos autores.

4 Maringá-PR é conhecida como cidade canção por conta da origem do nome da cidade, batizada em homenagem à música "Maringá", de Joubert de Carvalho. Os desbravadores da região cantavam incessantemente esta canção enquanto derrubavam as matas. Com o tempo, a alcunha se consolidou, devido justamente à estreita relação do município com a música sertaneja e, posteriormente, com os festivais de música.

Todas as falas e dados de João Pereira presentes neste artigo foram retirados de tais entrevistas, referenciadas ao fim do texto.
} 
escopo a linguagem audiovisual. Dias Pereira aproxima o movimento da "linha melodramática de representação":

\begin{abstract}
Seguindo a pista dada por Tinoco quando afirma que o "enredo tinha coisa pra rir e pra chorar" entendemos que peça Luar do Sertão - sem querer enquadrá-lo em um gênero, elemento que engessaria nossa análise - traz em si características da linha melodramática de representação, cuja produção, direção e texto eram feitas pelos próprios cantores auxiliados pelos atores circenses. Com isso, entendemos que a produção do teatro caipira, cuja finalidade era a divulgação da música caipira e da dupla de cantores, conforme nos afirmou o próprio Tinoco, filia-se à estrutura circense brasileira, calcada, como já dissemos, no circo-família, vinculando-se a uma arte "artesanal", distanciando-se de produções em moldes industriais que pressuporia uma maior racionalidade de produção artística (Pereira, 2008, p.59).
\end{abstract}

Dias Pereira, em sua pesquisa, diz respeito à prática da dupla sertaneja paulista Tonico e Tinoco e à relação das obras sertanejas com produções cinematográficas. A partir disso encontramos duas divergências entre a análise do autor e a do movimento no qual o presente texto se debruça: a primeira, de escopo, tendo em vista que o Teatro Caipira se enquadra como uma arte da cena, mais especificamente um tipo de teatro popular, a outra se dá pelo local, pois as obras referidas pelo autor são criadas no estado de São Paulo, e por uma dupla sertaneja que se consolidou no cenário nacional. Aqui, trataremos da região Norte do Paraná - que possui uma proximidade geográfica com o interior paulista - e de um artista que teve outro encaminhamento em sua vida.

Ditas as diferenças, agora nos restam as semelhanças. Há características comuns como a forte ligação com a música caipira, os meios de produção artesanais de músicos que desempenhavam todas funções necessárias para a cena e a ligação direta da apresentação com os meios de comunicação massivos, como rádio e televisão, que por consequência estão atrelados à música sertaneja - qualidades que tangem, em menor ou maior grau, um dito teatro popular (Rabetti, 2000). Embrenhados em tais distinções que nos apresentam valiosas pistas para o entendimento material e reflexões de um nominado Teatro Caipira, adentramos agora uma breve biografia de João Pereira. 
A cidade canção e João Pereira: Passos do poeta grão de areia no Teatro Caipira do norte do Paraná

\section{O poeta grão de areia}

João Pereira nasceu em Bauru, interior de São Paulo, em 1932. Seus grandes sonhos envolviam a advocacia e o futebol: com 11 anos, já treinava entre os adultos e tinha uma grande vocação para os estudos. Mas os dois planos foram tomados pela Segunda Guerra Mundial. Como seu pai era inspetor de quarteirão no município paulista e liberava da cadeia muitos italianos e japoneses que falavam seus idiomas nativos, passou a sofrer ameaças constantes de prisão e morte. Por isso, vendeu seu sítio com trinta alqueires de terra e cinquenta mil pés de café e veio com a família para Apucarana, no Norte do Paraná.

Figura 1 - João Pereira recita um de seus poemas

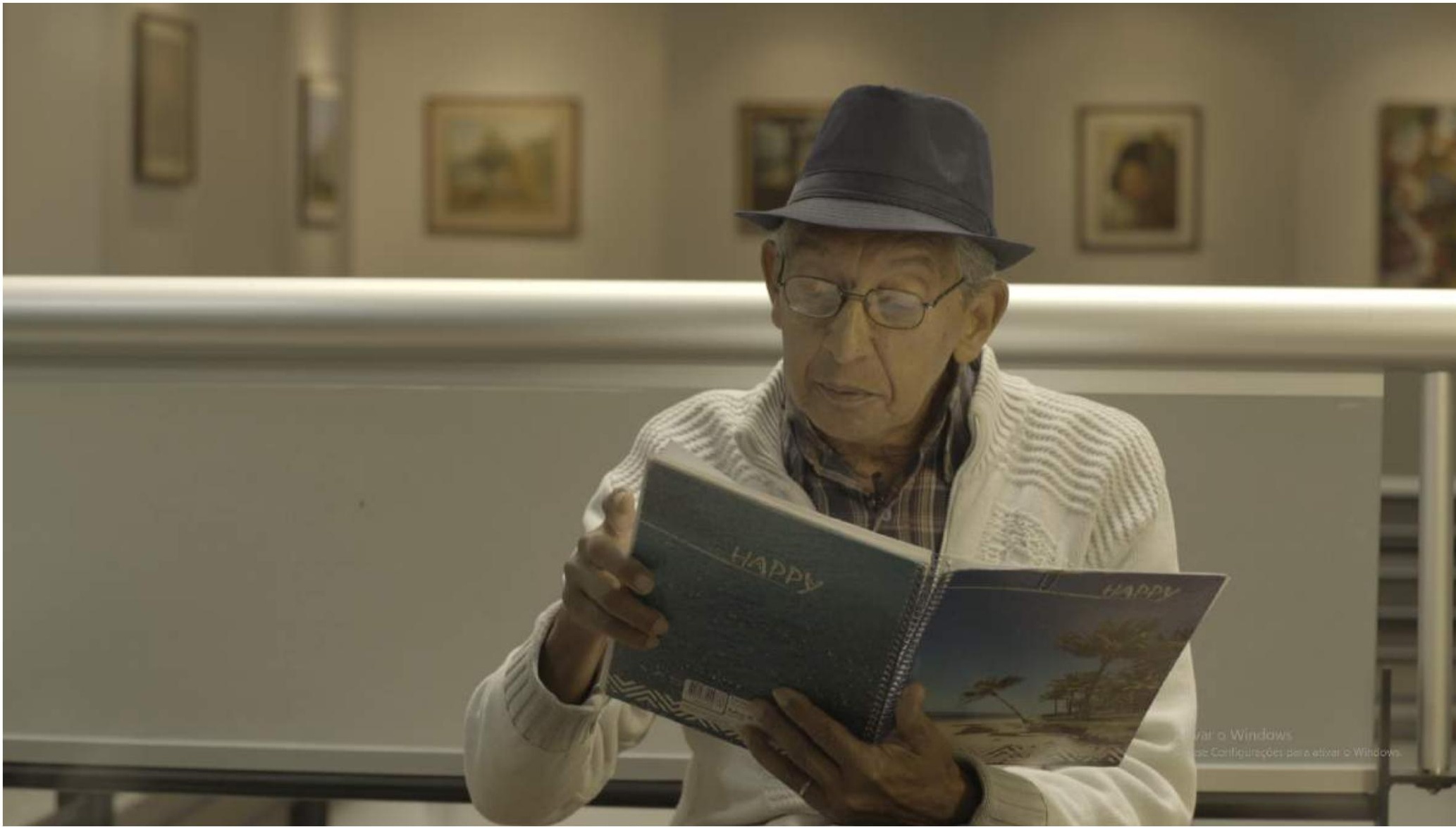

Fonte: Filme Cidade Canção, 2018

Sobre o momento da mudança, João Pereira relata: "desapareceu meu futebol e desapareceu a minha vocação pro estudo. Aí, o meu Espírito Santo, meu 
santificador, nosso, de todos nós, me iluminou e me deu essa vocação da poesia, da música". Sua trajetória musical começou com o pandeiro e com o reco-reco nos grupos de seresteiros que cantavam embaixo das janelas das casas de Mandaguaçu, município que, hoje em dia, possui pouco mais de vinte mil habitantes. Então, João Pereira entrou como pandeirista no grupo Suingue Jazz, também de Mandaguaçu. Em pouco tempo se tornou baterista do conjunto, no qual permaneceu tocando entre 1950 e 1955. No entanto, sua paixão se tornou a música sertaneja e seu novo sonho, entrar no mundo do rádio.

Foi o que aconteceu no dia 10 de maio de 1957, aniversário de 10 anos do município de Maringá, a 18 quilômetros de Mandaguaçu. A Rádio Cultura, principal da região, organizou um concurso para novos talentos, com a temática de dia das mães. João Pereira, que na época trabalhava como vendedor de café para seu pai, veio se apresentar com seu irmão, Pereirinha, e cantou uma música de autoria própria, um xote intitulado Gaúcho de Jaguarão. A apresentação foi amplamente aplaudida e se destacou em meio aos vários covers que estavam sendo reproduzidos pelos demais participantes. No intervalo da apresentação, os donos da Rede Paranaense de Rádio, Samuel Silveira e Joaquim Dutra, telefonaram para o locutor do programa e disseram: "Esse menino não pode ficar no sítio". Na volta para casa, João Pereira já tinha em mãos uma proposta para trabalhar na Rádio Cultura. Então, acabou divergindo de seu pai, que afirmava que toque de viola não enchia barriga. João respondeu: "Pai, toque de viola não enche barriga, mas diverte. E a viola também abre caminhos, outros caminhos”.

Um dos caminhos abertos pelo toque de viola foi o do teatro. Após passar alguns anos como auxiliar de locutores na Rádio Cultura em Maringá-PR e ganhar os seus próprios programas, como o Sertão de Ouro, João Pereira se consolidou também como compositor sertanejo. Seu maior sucesso foi a música Tarde Demais, que foi gravada pela sua dupla João Pereira e Zé Moreno e, de acordo com ele, é pedida até hoje nas rádios brasileiras. Mas, com o passar do tempo, João Pereira passou a sentir necessidade de produção própria também no teatro. Então, com um nome forte na cena sertaneja de Maringá, que era um dos principais polos do gênero no país, se juntou ao locutor Orlando Manin, conhecido como Coronel do Rancho, e propôs a fundação da Sociedade Cultural dos Artistas do Norte do 
Paraná (SCANP). Para arrecadar verbas para a formalização da entidade, os dois passaram a realizar shows semanais nos circos da região. Os shows eram compostos por apresentações de duplas sertanejas e encenações de dramas e comédias escritas pela própria equipe. Então, em um determinado domingo, não havia nenhum circo disponível para abrigar o show, o que fez com que o Coronel do Rancho pedisse emprestado o auditório da Rádio Cultura para a realização do espetáculo. Durante a semana, os locutores divulgaram que a caravana do João Pereira se apresentaria no auditório e que a entrada seria cobrada. No domingo, o auditório foi ocupado pela capacidade máxima, de 323 lugares, e muitos espectadores ainda acompanharam o show sentados nas laterais. Ao final, foi encenado um dos dramas produzidos pela caravana. Assim como no início da carreira de Pereira, os donos da Rede Paranaense de Rádio telefonaram imediatamente e propuseram um programa fixo com a mesma proposta do show, que passaria a acontecer todos os domingos na Rádio Cultura.

A partir disso, a caravana do João Pereira passou a produzir peças em ritmo semanal e o programa ganhou um nome: Maringá se diverte. Entre segunda e quarta-feira, a peça era escrita. Ainda na quarta, o enredo era enviado para a Polícia Federal em Londrina. Se fosse aprovado, o grupo tinha dois dias para terminar de montar o figurino. As peças encenadas sempre acompanhavam uma moda de viola composta por algum dos participantes da caravana, já que quase todos do grupo se dividiam entre a vida como músico sertanejo e os shows semanais. Faziam parte do núcleo central do grupo: Cafezinho (José Raia Neto), humorista e compositor de músicas caipiras ${ }^{6}$; Dioguinho (Antônio Francisco da Silva), humorista e cantor sertanejo; Coronel do Rancho (Orlando Manin), locutor de programas sertanejos e compositor ${ }^{7}$; Vieira da Silva (Joaquim Divino), costureiro, que montava todo o figurino e sempre interpretava os bandidos nas encenações; Serrote (Victor Andreatta), pioneiro do circo maringaense que se tornou diretor artístico da Rádio; e Tercílio Men, conhecido por ser o primeiro sanfoneiro da cidade, que

${ }^{6}$ Entre suas composições, destaca-se a música Seresteiros da Lua, que fez sucesso ao ser gravada pela dupla Pedro Bento e Zé da Estrada.

Coronel do Rancho testemunhou a criação do ritmo Pagode, que ocorreu em seu estúdio e revolucionou a música sertaneja. As primeiras dedilhadas do novo ritmo foram dadas por Tião Carreiro, cuja presença era constante em Maringá. Entre as composições próprias de Orlando Manin, o maior destaque é Pecado de Mariposa, música gravada por Zezinho e Zorinho. 
acompanhava os músicos durante as apresentações.

Figuras - 2 e 3 - Programas de Teatro Caipira não preenchidos
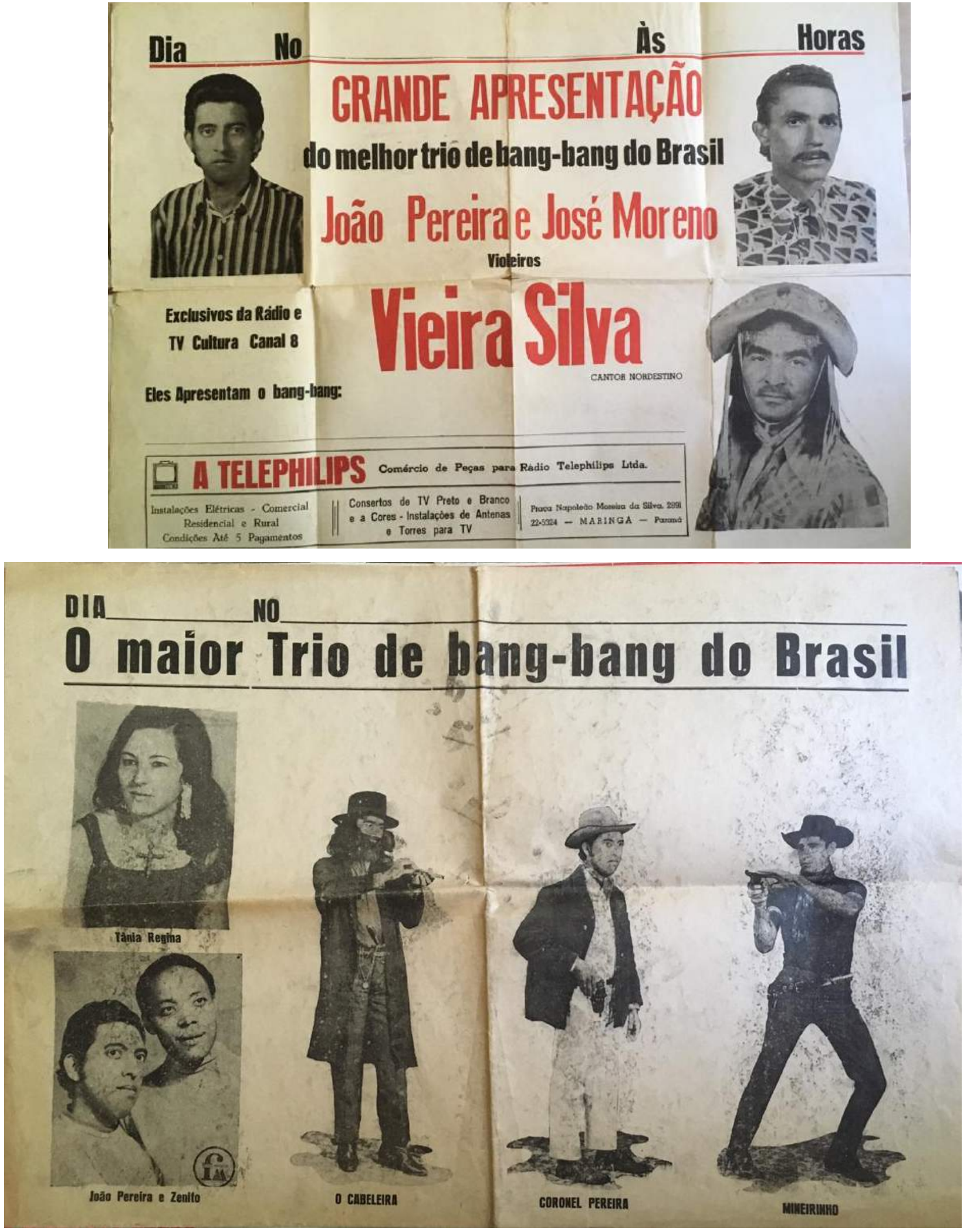

Acervo: João Pereira 
Durante quase uma década, a caravana de João Pereira se apresentou em praticamente todas as cidades da região Norte do Paraná, sempre com grande sucesso de público. O movimento do bang-bang sertanejo começou a chamar a atenção da indústria cinematográfica, o que fez com que João Pereira recebesse um convite oficial para se reunir com a produtora BRÁS-FILMES, que pretendia utilizá-lo em uma espécie de "cinema caipira". Mas, por motivos familiares, Pereira recusou a ideia. Até hoje fala com ressentimento sobre o episódio, acreditando que conseguiria eternizar suas histórias caso tivesse tomado outra decisão. Os tempos áureos do programa Maringá se diverte e das apresentações do Teatro Caipira foram chegando ao fim à medida que a televisão se consolidou nos lares dos maringaenses. Depois disso, João Pereira fundou a primeira gravadora de discos sediada em uma cidade no interior do Brasil, a gravadora Itaipú, com foco na gravação de artistas sertanejos da região. O primeiro disco foi de sua própria dupla, João Pereira e Zé Moreno, intitulado Os seresteiros do Brasil. No entanto, por conta da emergência de grandes gravadoras de nível nacional, a Itaipú não durou muito tempo. Depois, João Pereira continuou como apresentador de programas sertanejos até 2008. Hoje em dia, mantém o seu quartinho de poesias, composições e orações. Os poucos registros da época do Teatro Caipira estão sob sua posse, mas com o tempo os cadernos em que roteirizou as peças acabaram se tornando rascunhos para os rabiscos dos filhos e netos. Em Maringá, não é muito reconhecido, principalmente pelas novas gerações. Uma de suas últimas aparições na mídia foi em reportagem da TV local sobre a dificuldade que os idosos têm para atravessar a rua em uma região sem semáforo, na qual foi entrevistado como transeunte.

Para além de uma carreira de sucesso na região de Maringá ou do convite de uma das maiores produtoras de cinema brasileiras, a trajetória de João Pereira nos aponta um rico território de criação cênica, em que música caipira e teatro se misturam, no chamado Teatro Caipira. Como é notável na vida dos artistas, as qualidades da música sertaneja, organizada por duplas ou trios, estavam imbricadas com as do teatro, como descrito nos programas de peça - expostos anteriormente no texto, nas figuras 2 e 3 - como o maior, ou melhor, "trio de bang- 
bang do Brasil". Nesses mesmos programas, não é mencionado o título dos espetáculos ou das peças. A partir dessa constatação, é possível apreender que os nomes dos intérpretes se tornaram o centro, o eixo principal do espetáculo. Neste caso, um artista como João Pereira era o próprio espetáculo. Isso posto, podemos adentrar a dramaturgia, escrita pelo próprio João Pereira, para entender os temas e técnicas do Teatro Caipira.

Figura 4 - Carta da BRAS-FILMES Ltda. enviada a João Pereira

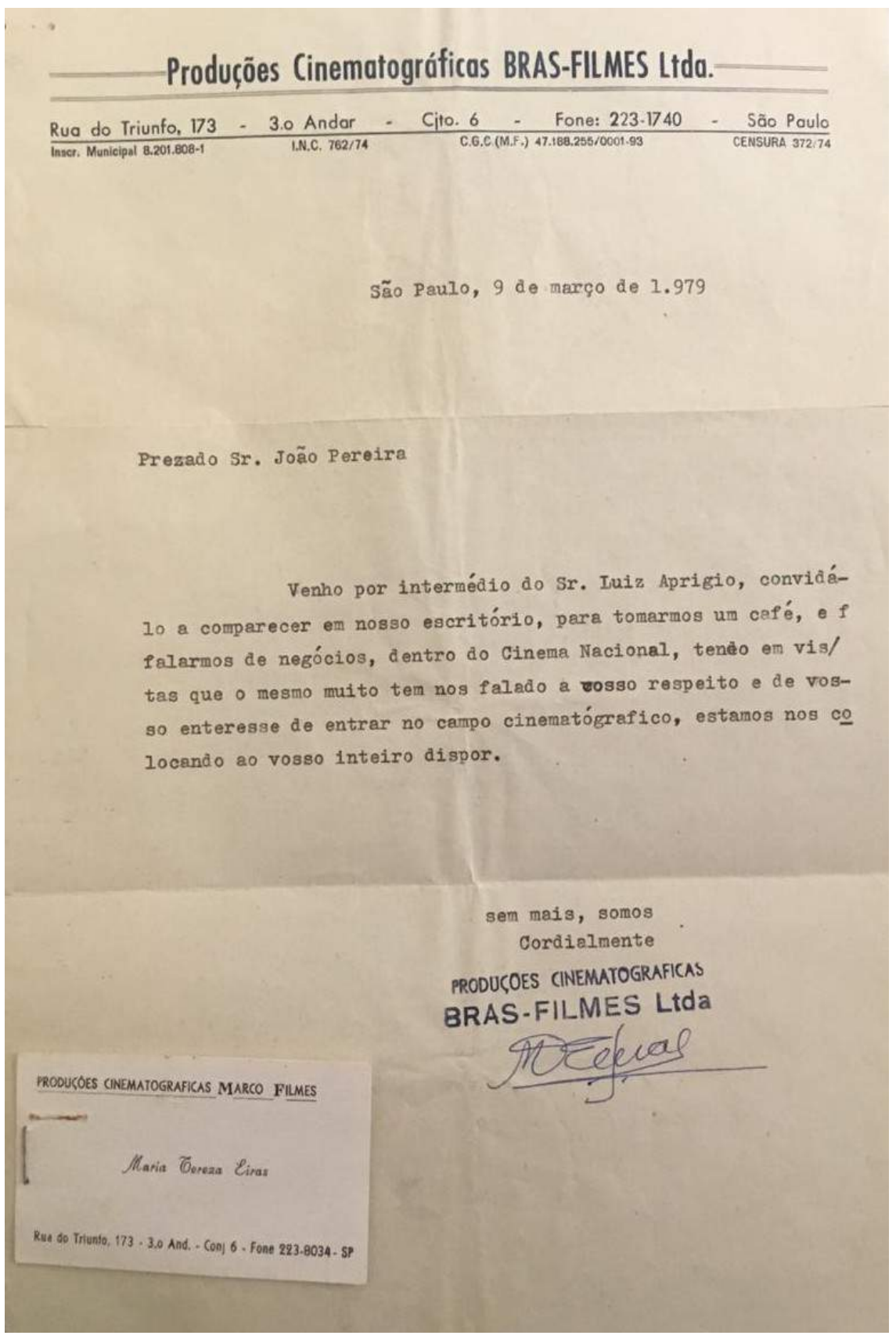

Acervo: João Pereira 


\section{O Teatro Popular na peça Corisco antes de ser cangaceiro,} de João Pereira

Para dar mais materialidade e proximidade à dramaturgia do Teatro Caipira, tomamos como exemplo a peça Corisco antes de ser cangaceiro, escrita por João Pereira em 14 de março de 1968. Em uma primeira observação do título da obra, podemos presumir uma continuação da peça em que o personagem Corisco é cangaceiro. Nisso encontramos a manifestação do que seria a dramaturgia seriada - utilizada no Rádio Teatro e muito comum nas peças de Teatro Caipira -, que advém dos mecanismos de produção cênica atrelados a uma equipe artística e aos papéis fixos, que por fim são vinculadas à música sertaneja, como descrito anteriormente.

A peça trata-se de um melodrama dividido em cinco atos - tal divisão está ligada às transições espaciais, no sentido tradicional de uma divisão de atos de dramaturgia, e também às modas de viola tocadas entre cada ato. A peça em questão conta a história de Joaquim, um homem desempregado que, ao ver seu filho (José) e sua esposa (Maria) quase morrerem de fome, decide mendigar para alimentar sua família.

No segundo ato, Joaquim vai até a casa do latifundiário Antônio e the pede emprego. O rico homem trata Joaquim com desprezo e soberba, ao the dizer "O que eu tenho que seu filho morra de fome, para mim podem morrer todos", Joaquim sai e continua a perambular para conseguir comida para seu filho José. Em seguida, no terceiro ato, Joaquim chega à casa de João, outro fazendeiro, esse, dono de uma pequena propriedade. João se compadece com a causa de Joaquim e promete the dar trabalho e moradia para viver uma vida digna.

Os dois atos seguintes se passam 15 anos depois, e o conflito é a grilagem de terras, que se dá pelo desejo de Antônio de comprar as terras de João. Devido à tal resistência, João se torna vítima dos desejos de Antônio e alvo de ameaças de morte, feitas pelo latifundiário e seus capangas. Por fim, João é salvo por José, filho de Joaquim, que diz ter sonhado há muito tempo que veria o sangue correr

\footnotetext{
${ }^{8}$ As citações da peça seguem exatamente o que foi escrito no roteiro original, sem alterações ou correções.
} 
no Sertão, e acaba com os capangas de Antônio "como um relâmpago", tornandose o justiceiro nos sertões. Graças à agilidade, João batiza José de Corisco. Como recompensa, João oferece metade de suas terras para Corisco, que não as aceita, alegando haver outro homem que necessita de sua ajuda: Lampião9 .

À primeira vista, pode tratar-se de uma peça com certo tom popular, tanto em sua forma, como já descrito na vida do poeta, compositor e ator João Pereira, tanto pelos temas abordados, que dialogam com a cultura popular. Neste caso se faz necessária uma definição para o "teatro popular", que é pertinente para a análise da obra. No texto Memória e Cultura do "Popular" no Teatro: O Típico e as técnicas, a pesquisadora Beti Rabetti define em síntese três tipos:

Nesta direção, se eu estendesse uma linha para acompanhar este conjunto extremamente diversificado, em uma das extremidades estaria um teatro de cunho político mais explicitamente empenhado e, em outra, um teatro preponderantemente ingênuo e singelo, onde comumente sobressaem tons de folclore. No centro nevrálgico desta linha de tensões eu situaria o teatro popular visto como ligeiro ou comercial (Rabetti, p.3, 2000).

Identificamos a peça de João Pereira situada neste "centro nevrálgico" entre o que seria um teatro político e outro ingênuo, de entretenimento. Essa percepção se dá por dois fatores: o primeiro, as críticas sociais retratadas na ação de grilagem de terras pelo personagem Antônio e seus capangas; o segundo são as cenas de comicidade e alívio como as do, até aqui não citado, empregado Bagunça. Neste momento, vamos analisar tais trechos:

${ }^{9}$ Esta peça terá como continuidade A morte de lampião (1968) e outras em que os mesmos personagens estão presentes. 


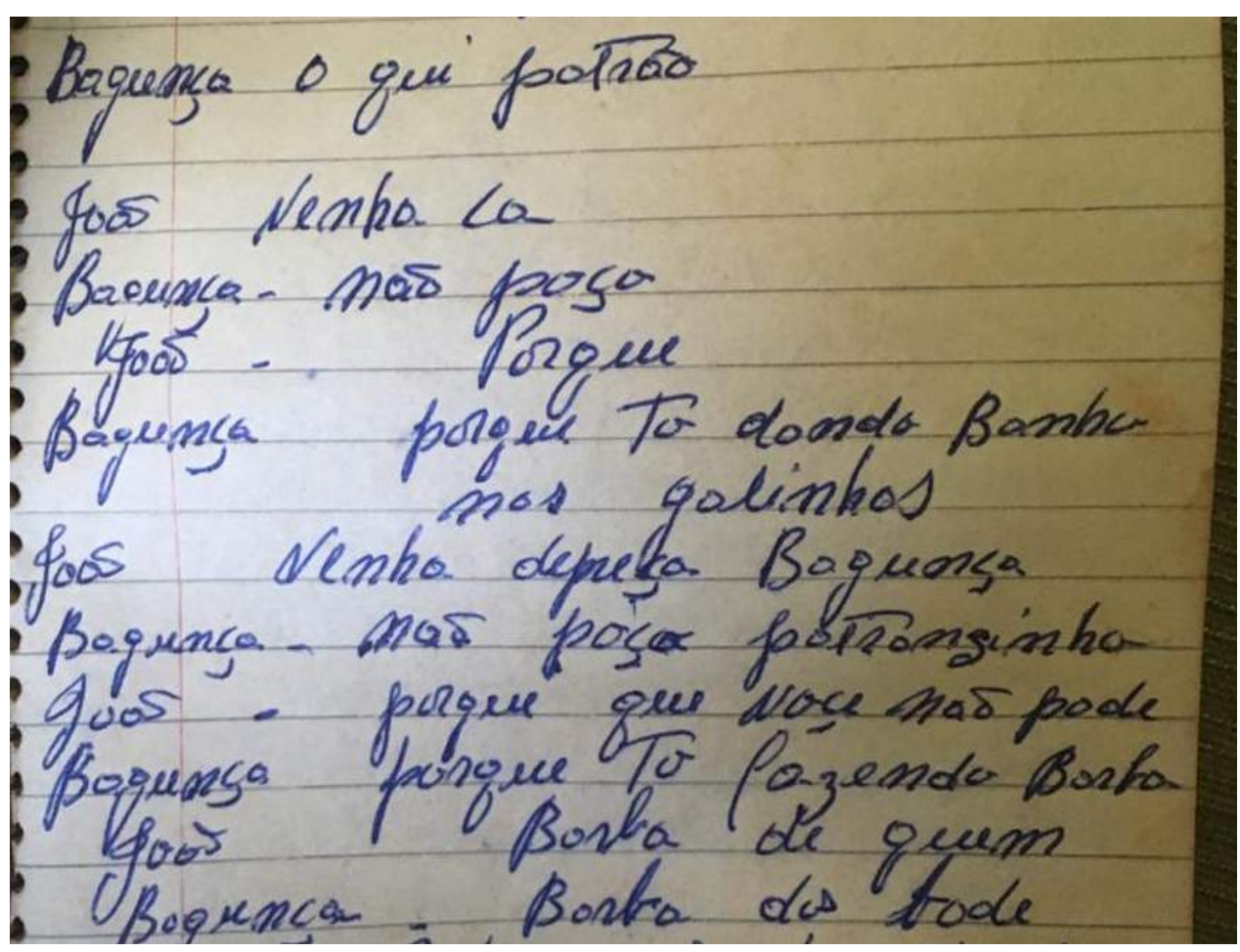

Acervo: João Pereira ${ }^{10}$

Como podemos observar, o trecho acima apresenta um diálogo de tom arlequinesco, que remete à lógica patrão e criado, comumente empregada na Commedia dell'arte. Não queremos discutir se tal estilo de teatro tinha relação direta ou não com a forma teatral italiana, mas, em todo caso, a semelhança entre ambas revela algo de sua lógica de produção cênica, ao considerarmos que a dramaturgia está diretamente ligada aos mecanismos de atuação estruturada por tipos, assim como na Commedia dell'arte (Kodi, 2019), em que a dramaturgia é suscetível aos improvisos dos atuantes. O personagem Bagunça, cujo nome remete diretamente à sua função cômica na peça, era desempenhado, assim como os demais personagens cômicos criados pelo grupo de João Pereira, por Dioguinho (Antonio Francisco Silva) ou Cafezinho (José Raia Neto). Como expõe o historiador João Laércio Lopes Leal:

10 Transcrição: BAGUNÇA - O que Patrão. JOÃO - Venha cá. BAGUNÇA - Não posso. JOÃO - Por que? BAGUNÇA - Porque tô dando banho nas galinhas. JOÃO - Venha depressa Bagunça. BAGUNÇA - Não posso patrãozinho. JOÃO - Por que você não pode? BAGUNÇA- Porque tô fazendo a barba. JOÃO - Barba de quem? BAGUNÇA - Barba do bode. 
Cafezinho era o apelido de José Raia Neto, nascido em Arapongas/PR, aportado em Maringá na década de 1950. Dono de talento humorístico acima da média, possuía grande habilidade de improvisação. Ficou célebre sua apresentação na praça central do distrito Sarandi/PR, pois, ao cair da escada, quando subia ao palco, aproveitou a queda e a utilizou como atração para o número que ia encenar em seguida (Leal, p. 125, 2016).

Figura 6 - Dioguinho e Cafezinho ensaiando

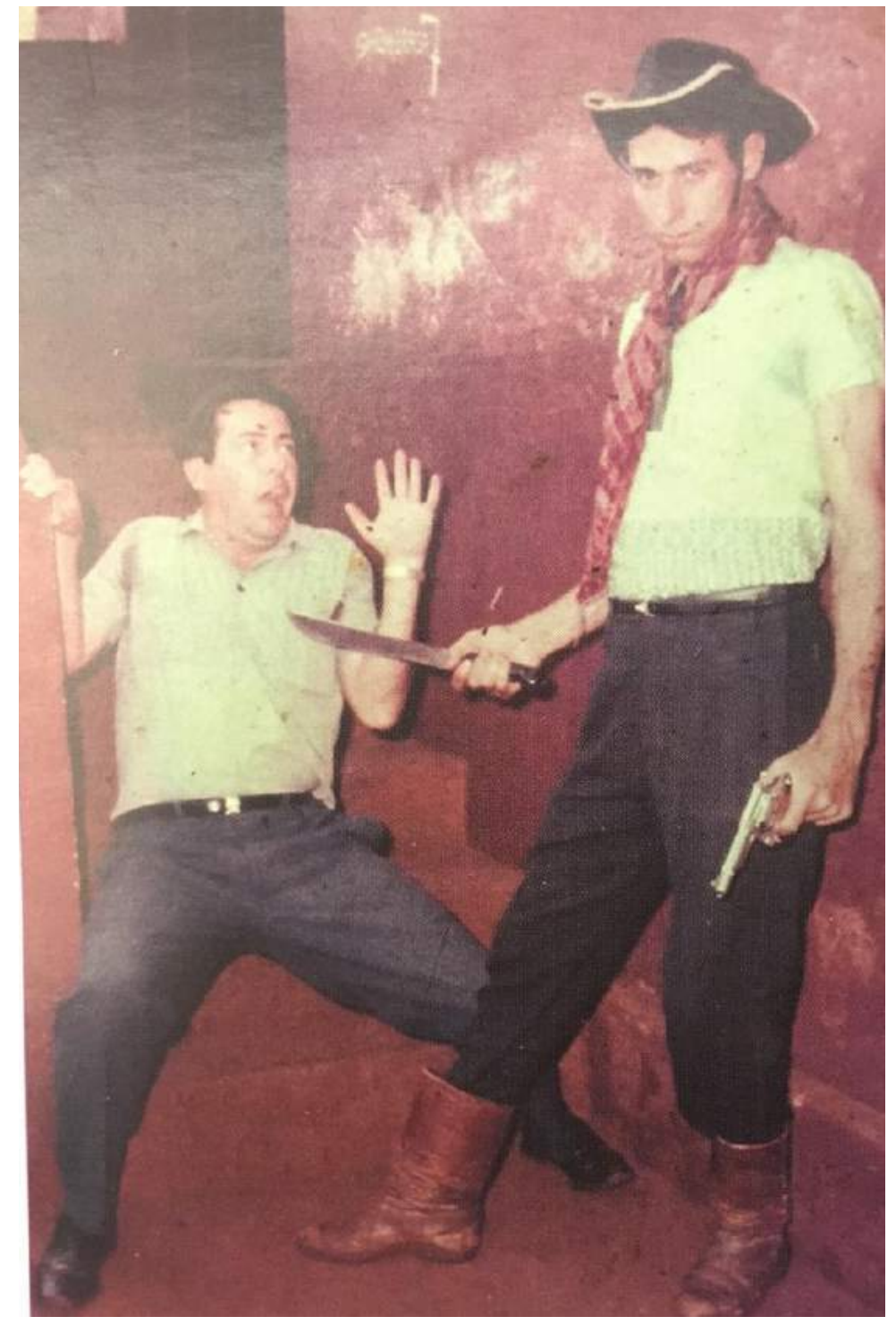

Acervo: Lincoln Copceski

Como evidenciado por Leal, a improvisação dos atores - que desempenhavam também a função de músicos - foi presente no Teatro Caipira. Isso nos permite inferir, em relação ao citado trecho da peça, a porosidade do 
enredo em relação aos improvisos cômicos realizados pelos atuantes. Essa porosidade aproxima o movimento das características atreladas ao teatro popular, de caráter cômico, com foco deslocado do texto para a relação com o público.

Entretanto, essas marcas de um teatro de entretenimento não excluem o caráter político que caracteriza a outra ponta do teatro popular, anteriormente mencionadas por Rabetti (2000). Apresentamos outro trecho da obra, em que os mesmos personagens, João e Bagunça, dialogam comentando as ameaças do latifundiário Antônio:

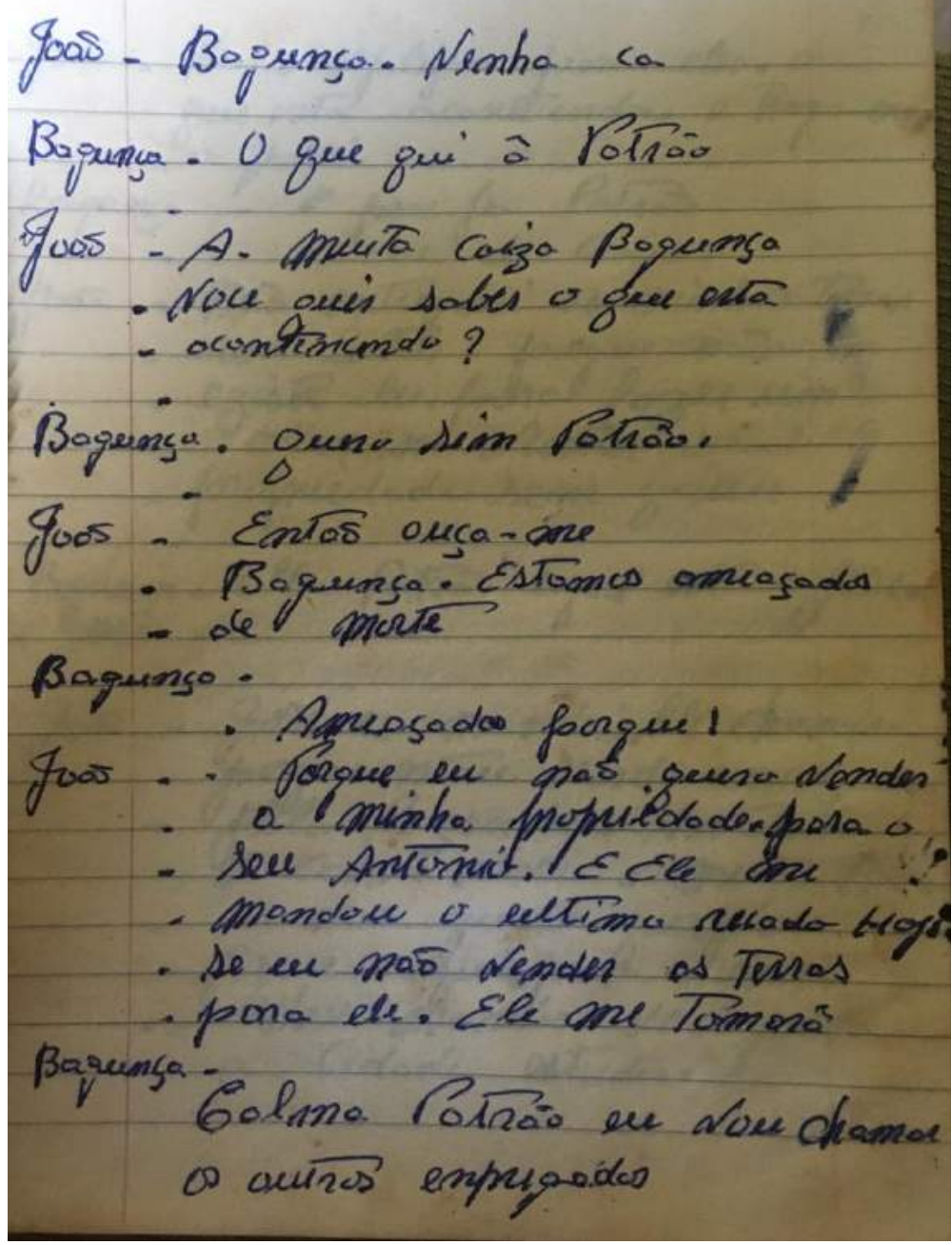

Acervo: João Pereira ${ }^{11}$

${ }^{11}$ Transcrição: JOÃO - Bagunça venha cá. BAGUNÇA - O que é Patrão? JOÃO - A, muita coisa Bagunça, você quer saber o que está acontecendo? BAGUNÇA - Quero sim patrão. JOÃO - Então ouça-me: Bagunça, estamos sendo ameaçados de morte. BAGUNÇA - Ameaçado por quê?! JOÃO - Porque eu não queria vender a minha propriedade para o Seu Antônio e ele me mandou o último recado hoje, se eu não vender as terras para ele. Ele me tomará. BAGUNÇA - Calma Patrão eu vou chamar os outros empregados. 
No trecho acima, os personagens - anteriormente referidos em outra passagem da peça, em uma cena explicitamente cômica - demonstram características mais dramáticas em relação aos interesses de Seu Antônio. O diálogo denota o conflito dos pequenos agricultores com a grilagem de terras por parte dos latifundiários. Tais conflitos eram comuns em Maringá e em todo o Norte do Paraná, como descreveu Jorge Ferreira Duque Estrada, em sua obra Terra Crua $(1961)^{12}$, e que João Pereira relata nos personagens e na dramaturgia de seu Teatro Caipira.

\title{
Maringá Terra Crua, temas e conflitos presentes no Teatro Caipira
}

As temáticas de Corisco antes de ser cangaceiro e de outras peças do grupo quase sempre envolviam conflitos que estavam presentes na cidade de MaringáPR, mas que eram ocultos pelos interesses do progresso. A região começou a ser colonizada na década de 1930, quando chegaram os primeiros desbravadores a serviço da Companhia de Terras do Norte do Paraná, que fazia parte do grande projeto de conquista do Oeste brasileiro. Em um vídeo institucional da Companhia, fica evidente o pensamento da época na região:

\begin{abstract}
Nas matas ao norte do Paraná sobressaem as árvores que já significam por si mesmas os padrões de terra fértil: a figueira branca, o palmito, o pau-d'alho. A terra roxa era um convite promissor à expansão da cafeicultura, provocando a grande corrida. Nessa região o homem pode escolher onde surgirá uma nova cidade... E a cidade surgirá. E então com toda a alma pioneira dos brasileiros, prosseguiu a penetração na mata bravia, com a vontade de vencer, de conquistar o agreste, de civilizar o desconhecido. O Paraná foi um milagre da livre iniciativa no setor da colonização. Há dez, vinte, trinta anos, levas pioneiras buscaram aquelas áreas desconhecidas, transformando empolgantemente as florestas compactas do estado promissor. Aqui se queimam as matas, mas desse fogo não resulta destruição, e sim riqueza coletiva (Vídeo, 2015).
\end{abstract}

A historiografia oficial do município, tendenciosamente abarcando os interesses da iniciativa privada, sempre fez questão de ofuscar todos os conflitos que se deram durante "a grande corrida". A região foi palco de muita violência, principalmente envolvendo os grileiros de terra. Ainda assim, a imagem vendida

${ }^{12}$ Citado por Dias e Gonçalves, 2011. 
sempre foi a de pacificidade, cidade modelo e de desenvolvimento meteórico principalmente após a crise cafeeira, quando o discurso do pioneirismo passou a prevalecer. De dentro do maior veículo de comunicação do Norte do Paraná na época, João Pereira e sua caravana conseguiram apresentar novamente a Maringá de verdade, falando sobre o tema ao público que viveu parte do período conflituoso. Todas as histórias eram repletas de crimes e tiros, o que fez com que o movimento fosse chamado de "bang-bang sertanejo" por João Pereira:

Então nasceu essa ideia do bang-bang sertanejo. Então a gente produziu esse Billy Gancho. Ó, Estados Unidos tem, vamo produzir uma coisa cabocla aqui imitando um pouco lá e tal. Então a gente produziu esse Billy Gancho, que eu fazia o papel do Billy Gancho mesmo e tal. Então, o que que acontece: tiro por todo lado, né, não havia festim que chegasse. Ainda bem que a arma de fogo era boa né, não falhava. O festim explodia mesmo. (João Pereira)

\section{Figura 8 - João Pereira interpretando o personagem Billy Gancho}




Um retrato dessa Maringá violenta foi feito por Joaquim Duque Estrada (1961) em seu livro Terra Crua, o primeiro escrito no município, que tratava a própria cidade como um objeto de disputa. Em uma interpretação da obra, os historiadores Reginaldo Dias e José Henrique Rollo Gonçalves aproximaram o cenário da terra crua maringaense ao do faroeste cinematográfico do imaginário norte-americano - assim como o bang-bang sertanejo propunha:

Segundo ele, tudo começou com a "cidade fantasma", nome que evocava precárias casas de madeira que não abrigavam ninguém, erguidas para que os contratos de compra, que previam edificações em curto espaço de tempo, não fossem feridos. Os homens e as mulheres viviam nas ruas dos cafezais, como colonos, volantes, desmatadores e, sobretudo, pequenos e médios proprietários. No que seria a cidade, sobravam silêncios e escuridões. E as toras encarvoadas, que avisavam da exuberância das matas mortas, "lembravam uma povoação abandonada", onde era preciso caminhar "evitando as emboscadas". Quem nunca viu esse cenário em filmes de bangue-bangue?" (Dias e Gonçalves, 2011, p. 33).

Figura 9 - Ensaio de peça da caravana de João Pereira

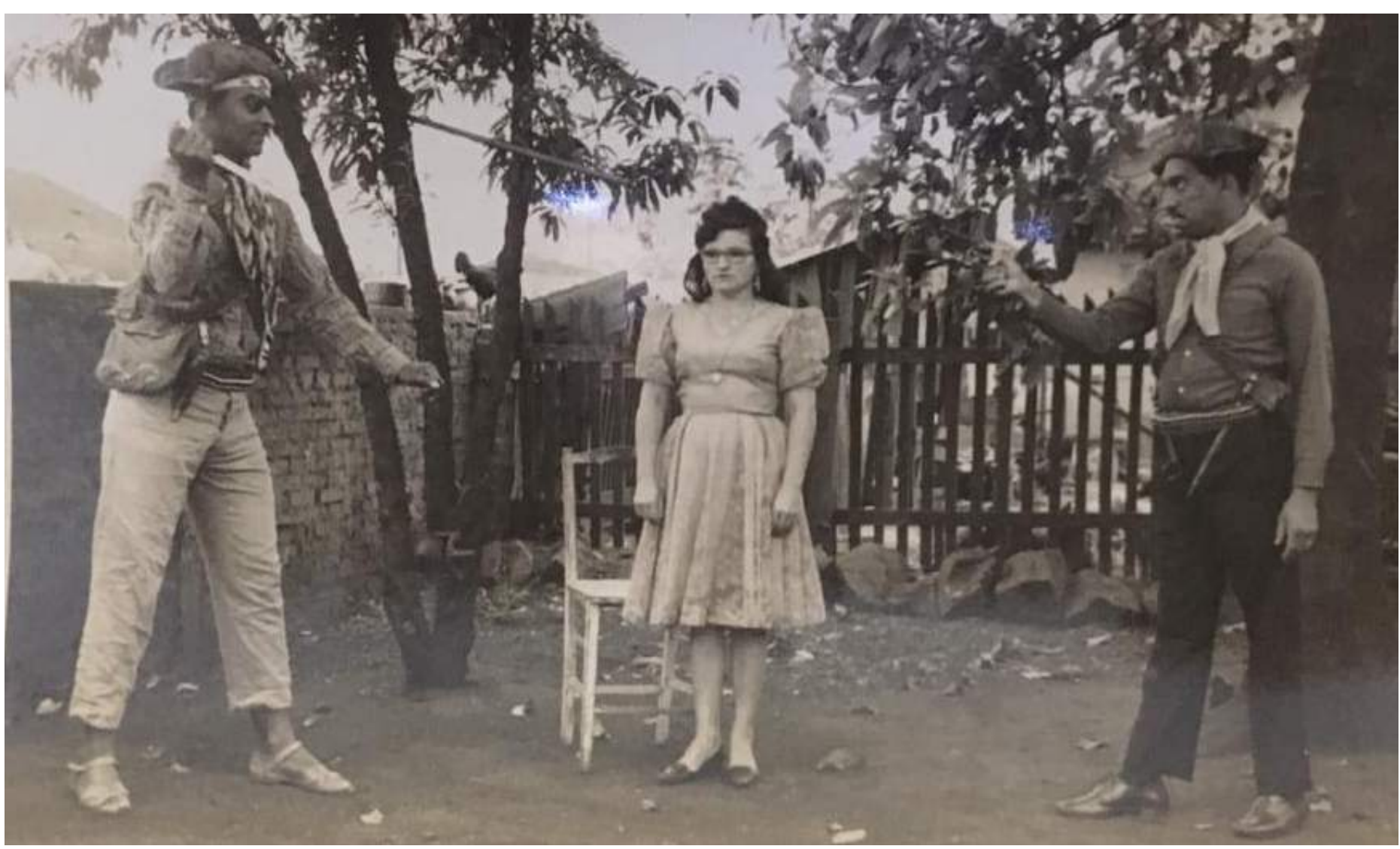

Acervo: João Pereira 
Na análise das ressonâncias do livro, os historiadores comentam como a Maringá crua foi sendo ofuscada por outros discursos, o que reforça a importância de João Pereira e seu grupo conseguirem, através do teatro, resgatar um imaginário coletivo que foi quase que forçadamente substituído:

\begin{abstract}
Muitas das grandes fortunas acumuladas na década anterior foram transferidas para São Paulo, Curitiba, Rio de Janeiro ou para novas frentes pioneiras, como estava previsto pelo próprio Duque Estrada. Houve, também, decadências memoráveis. Ademais, a ditadura militar impôs profundas modificações no modo de fazer política. Em face de tão rápidas mudanças, episódios dos primeiros tempos maringaenses escorreram pelas frestas das lembranças coletivas. Os novos donos do poder local não queriam saber de fatos pouco edificantes e os velhos achavam bem melhor esquecê-los. Assim, correspondendo ao novo contexto, livros e matérias jornalísticas voltadas para o passado local assumiram funções mais adequadas aos projetos de reengenharia da memória acalentados pela elite dominante. A mitologia da glorificação pioneira, padrão de organização das recordações coletivas que predomina nas áreas de colonização bem-sucedidas, consagrou-se (Dias e Gonçalves, 2011, p. 37).
\end{abstract}

Peças como Corisco antes de ser cangaceiro tinham a grilagem de terras e a reforma agrária como temáticas centrais. Outras peças encenadas também traziam à tona questões políticas, como O Ladrão de Terras, A Morte do Lampião, Cabeleira, o bandido sanguinário e Ana Rosa. A mais polêmica delas foi Os cruéis, baseada na história de Claudimar Pedrosa Lô - um menino de 15 anos que foi morto e torturado após ser acusado injustamente de roubo ${ }^{13}$. O grupo de João Pereira compôs uma música e produziu uma encenação sobre o caso, mas as duas obras foram derrubadas pela Polícia Federal de Londrina, sob ameaça de fechamento da Rádio Cultura.

Mesmo com tamanho engajamento político e social, os praticantes do Teatro Caipira sofriam com acusações de despolitização, assim como vários outros movimentos artísticos populares da época da ditadura militar brasileira. A deslegitimação do grupo na História da arte do município - e até do estado do Paraná - também se deu por meio de vários discursos desenvolvimentistas. Em um manifesto escrito em 1967 por Romão Poli Filho, proprietário da PROMAG Empresa de Loteamentos e Colonizadora, isso fica explícito: "Passada a fase inicial

${ }^{13}$ Hoje em dia, Claudimar Lô se tornou uma espécie de Santo Popular em Maringá. 
do pioneirismo agreste, é chegada a hora de voltarmos nossos olhos para uma evolução cultural tão violenta e surpreendente como foi sua evolução material" (Leal, 2016, p. 121). Dez anos depois, em 1977, a "pobreza cultural" das manifestações vigentes no município na época voltou a ser documentada, desta vez em uma análise retrospectiva do MTA - Movimento do Teatro Amador, entidade criada em 1977 por grupos que se dedicavam a um teatro de caráter erudito $^{14}$ na cidade, escrita por Tadeu Moacir Lima ${ }^{15}$ :

O quadro cultural e social do interior que predomina nas relações de qualquer movimento cultural que tenha surgido no norte do Paraná é um quadro muito precário, muito pobre. Esse movimento de teatro amador - o MTA - surgido em 1977, prolongando-se por quase todo esse ano, destacar-se-á dos outros, anteriores, porque tentou romper esse quadro social, pobre, de conotações rurais, provincianas, arcaicas, atrasadas em relação à própria história nacional (Leal, 2016, p. 165).

A repressão política sofrida por parte dos atuantes do Teatro Caipira reforça a crítica social e a subversão presentes nesse estilo teatral. Mas o próprio João Pereira, mesmo com tamanha importância para a arte da região, ainda se põe em contraste com os artistas letrados:

Porque nós, os caboclos, que somos pobres, nós se consideramos grão de areia. Por que grão de areia? Grão de areia porque é pobre, não tem dinheiro. Porque eu sou um poeta grão de areia, e tem o poeta letrado, que ele estudou filosofia, estudou advocacia, é professor. Quer dizer, ele é o poeta letrado. Esse é poeta, que eu chamo, considero e respeito como poeta. Agora, eu não. Eu sou um compositor sertanejo.

A posição de João Pereira, vestida de poesia e modéstia, não se trata, unicamente, da de um artista sertanejo que atravessa o teatro, ou mesmo um denominado teatro popular musical, ou ligeiro, ou comercial, nem da cisão dessa categoria de teatro com outra, considerada intelectual, que acompanha os interesses de progresso do estado. Nosella e Issene (2016), apontam essa visão ao comparar o teatro Realista brasileiro, do século XIX, e sua crítica a teatros de

${ }^{14}$ Que procurava replicar o modelo paulista de teatro em voga na época, que tinha o TBC como um dos maiores expoentes.

${ }^{15}$ Esta análise retrospectiva foi encontrada em Leal, 2016. 
caráter dito ligeiro, como o melodrama, as comédias de Martins Pena ou o teatro musicado:

\begin{abstract}
Sendo assim, tal percepção coloca o artista brasileiro num lugar de necessário posicionamento quanto à sua realidade, isto é, ao "tomar partido" de uma nacionalidade popular, não a nacionalidade de um projeto "livresco e ideológico", mas a efetivamente preocupada em olhar, refletir e dialogar com nossos problemas, tomaria partido de uma cultura popular revolucionária (Nosella e Issene, 2016, p. 312).
\end{abstract}

Consideramos que a obra de João Pereira, assim como o movimento do Teatro Caipira, não podem ser situados monoliticamente como um teatro de entretenimento que acompanha a ascensão da música sertaneja nas rádios porque foram um fenômeno na corda bamba entre ambas as pontas de um dito Teatro Popular - equilibrado entre o sucesso das tendências musicais de uma época e os conflitos políticos soterrados pelo interesse do progresso, e que, com boas medidas, caminhou como Teatro Caipira nos passos de João Pereira.

\title{
As heranças de um Teatro Caipira
}

Para alcançar o êxito artístico, João Pereira e sua caravana fizeram um resgate da memória coletiva ao estabelecer uma relação de identificação e cumplicidade com o público da região. Essa relação se dá através das operações simbólicas que ocorrem por conta da estrutura dramática das peças, que se aproxima da estrutura dos melodramas apontada por Martín-Barbero (2009, p.168169):

Tendo como eixo central quatro sentimentos básicos - medo, entusiasmo, dor e riso -, a eles correspondem quatro tipos de situações que são ao mesmo tempo sensações - terríveis, excitantes, ternas e burlescas - personificadas ou "vividas" por quatro personagens - o Traidor, o Justiceiro, a Vítima e o Bobo - que, ao juntarem-se realizam a mistura de quatro gêneros: romance de ação, epopeia, tragédia e comédia. Essa estrutura nos revela no melodrama uma tal pretensão de intensidade que só se pode alcançar à custa da complexidade.

Em Corisco antes de ser cangaceiro os mesmos tipos mencionados por Martín-Barbero se fazem presentes, sendo respectivamente: Antônio (o Traidor), José ou Corisco (O Justiceiro), João (a Vítima) e Bagunça (o Bobo). Esse 
A cidade canção e João Pereira: Passos do poeta grão de areia no Teatro Caipira do norte do Paraná

emaranhado de personagens, atrelado à trajetória de um artista que vivenciou o fenômeno do Teatro Caipira, traz à tona toda a intensidade e potencialidade que essa forma teatral teve e que poderiam ter sido soterradas caso o movimento fosse esquecido na História do Teatro.

Este artigo ensaiou uma visão panorâmica de um fenômeno teatral de suma importância e situado fora do eixo hegemônico do teatro brasileiro (Rio-São Paulo). Nós conhecemos João Pereira através de outra pesquisa, que envolvia a História da música maringaense. Seu nome não era e não é citado na História do teatro maringaense - e é menos conhecido ainda na História do teatro brasileiro. Nem o próprio João Pereira desvincula suas atividades teatrais de sua atividade musical: o músico e ator amalgama ambas em sua carreira na música sertaneja. Não pretendemos neste artigo abarcar todas as multiplicidades presentes no fenômeno do Teatro Caipira, mas sim, arriscar um passo na tentativa de inserir tal movimento na História e fornecer materiais para pesquisadores das mais variadas áreas que podem se interessar pelo fenômeno, como a musicologia, a teatrologia, a comunicação, a antropologia e a História. E, ao fim desta empreitada, quisemos prestar uma homenagem, mesmo que breve, ao poeta grão de areia.

\section{Referências}

CIDADE CANÇÃO: Os primeiros anos da música maringaense. Direção de Lincoln Copceski. Maringá: 2018. 1 DVD (96 min).

DIAS, Reginaldo Benedito; GONÇALVES, José Henrique Rollo. Maringá: terra crua e civilização. Revista Espaço Acadêmico, v. 11, n. 121, p. 28-39, 2011. Disponível em: https://periodicos.uem.br/ojs/index.php/EspacoAcademico/article/view/13607.

Acesso em: 10 maio 2021.

RABETTI, Betti. Memória e Cultura do "popular" no teatro: o típico e as técnicas. Percevejo, Rio de Janeiro, n. 8, p. 3-18, 2000.

KODI, Douglas. A utopia da Commedia dell'arte no século XXI: o Canovaccio, o ator e a cena. Dissertação (Mestrado) - Centro de Artes, Universidade do Estado de Santa Catarina, Florianópolis, 2019.

LEAL, João Laércio Lopes. História artística e cultural de Maringá: 1936-1990. Maringá: Imprima Conosco, 2016. 
MARTÍN-BARBERO, Jesus. Dos meios às mediações: Comunicação, cultura e hegemonia. 6. ed. Rio de Janeiro: Editora UFRJ, 2009.

NOSELLA, Berilo Luigi Deiró; ISSENE, Letícia Gouvea. Entre a estética e o político: caráter popular, "qualidade estética" e teatro brasileiro. Urdimento - Revista de Estudos em Artes Cênicas, Florianópolis, v. 2, n. 27, p. 296-314, 2016.

PEREIRA, Odirlei Dias. No rádio e nas telas: o rural da música sertaneja de sucesso e sua versão cinematográfica. Dissertação (Mestrado em Ciências Sociais) Faculdade de Filosofia e Ciências, Universidade Estadual Paulista, São Paulo, 2008.

PEREIRA, João. Corisco antes de ser Cangaceiro. Imagens e textos do acervo pessoal. 1968.

VÍDEO histórico dos primeiros anos de Maringá. 1 vídeo (12min12s). Postado pelo canal Maringá em fotos em 08 nov. 2015. Disponível em https://www.youtube.com/watch?v=qobEJ72kquk. Acesso em: 09 jun. de 2021.

Recebido em: 15/06/2021

Aprovado em: 12/08/2021 